\title{
PENGARUH STRES KERJA, BURNOUT DAN MOTIVASI KERJA TERHADAP KINERJA PERAWAT RSD MANGUSADA KABUPATEN BADUNG
}

\author{
I Putu Surya Bagiada ${ }^{1}$ \\ I Gusti Salit Ketut Netra ${ }^{2}$ \\ ${ }^{1,2}$ Fakultas Ekonomi dan Bisnis Universitas Udayana (Unud), Bali, Inedonesia \\ Email: bagiadasurya@gmail.com
}

\begin{abstract}
ABSTRAK
Kinerja adalah hasil seseorang secara keseluruhan selama periode tertentu dalam melaksanakan suatu tugas. Penelitian ini bertujuan untuk mengetahui pengaruh stres kerja, burnout dan motivasi kerja terhadap kinerja di RSD Mangusada. Jumlah populasi yaitu 186 orang perawat tetap, dengan menggunakan metode propotionate stratified random sampling. Sampel yang digunakan 127 orang. Pengumpulan data dengan observasi, wawancara dan penyebaran kuesioner. Teknik analisis yang digunakan adalah regresi linear berganda. Penelitian menemukan bahwa stres kerja dan burnout berpengaruh negatif dan signifikan terhadap kinerja perawat. Motivasi kerja berpengaruh positif dan signifikan terhadap kinerja perawat. Upaya dalam meningkatkan kinerja diharapkan perlu memperhatikan kenyamanan perawat saat bekerja dengan rekan serta perawat harus mendapatkan jadwal kerja yang sesuai, kemudian perlu untuk memperhatikan kemampuan perawat dalam menangani jumlah pasien di rumah sakit serta membuat suasana kerja agar tidak monoton. Memberikan target yang jelas, menumbuhkan rasa tanggung jawab terhadap pekerjaan dan memberikan apresiasi terhadap perawat akan memotivasi perawat dalam bekerja.
\end{abstract}

Kata kunci : Stres Kerja, Kelelahan Kerja, Motivasi Kerja, Kinerja

\begin{abstract}
Performance is the result of person's work in certain period by carrying out some tasks. This study aims to determine the effect of job stress, burnout and work motivation on performance at Mangusada Hospital. The population is 186 nurses with 127 people as samples, using propotionate stratified random sampling.. Multiple linear regression was used. The study found that job stress and burnout had a negative and significant effect on nurse performance. Work motivation has positive and significant effect on nurse performance. Efforts to improve performance are expected to need to pay attention to the comfort when working with colleagues and nurses must get the appropriate work schedule, then need to pay attention to the ability of nurses to handle the number of patients and make the work atmosphere not monotonous. Providing clear targets, fostering a sense of responsibility towards work and giving appreciation to nurses will motivate nurses to work.
\end{abstract}

Keywords: Job Stress, Burnout, Work Motivation, Performance 


\section{PENDAHULUAN}

Manusia merupakan salah satu unsur yang terpenting di dalam suatu organisasi. Tanpa peran manusia meskipun berbagai faktor yang dibutuhkan itu telah tersedia, organisasi tidak akan berjalan. Karena manusia merupakan penggerak dan penentu jalannya suatu organisasi. Semua organisasi membutuhkan manusia sebagai penggerak organisasi termasuk lembaga kesehatan. Lembaga kesehatan seperti rumah sakit hadir memberikan pelayanan kepada masyarakat melalui jasa pengobatan.

Persaingan lembaga kesehatan di Bali sudah semakin tinggi. Rumah sakit harus memiliki keunggulan pelayanan sehingga mampu mempertahankan diri dalam persaingan industri pelayanan kesehatan untuk mampu bertahan dalam persaingan. Rumah sakit harus memanfaatkan sumber daya yang dimiliki supaya mempunyai keunggulan yang kompetitif.

Perawat merupakan salah satu sumber daya terbanyak dan paling penting yang dimiliki oleh rumah sakit. Perawat memegang peranan yang penting karena terlibat langsung dengan pasien dan peran seorang perawat dalam memberikan pelayanan akan menentukan kualitas pelayanan.

Perawat merupakan sebuah profesi yang membutuhkan tanggung jawab dan kompetensi yang mumpuni untuk memberikan pelayanan kesehatan kepada pasien. Karena salah satu faktor yang mempengaruhi tingkat keberhasilan suatu lembaga kesehatan adalah kinerja perawatnya.

Kinerja merupakan suatu hasil yang dicapai oleh karyawan dalam pekerjaanya menurut kriteria tertentu yang berlaku untuk suatu pekerjaan (Robbins, 
2008:410). Perusahaan selalu mengharapkan karyawannya mempunyai prestasi, karena dengan memiliki karyawan yang berprestasi akan memberikan sumbangan yang optimal bagi organisasi. Kinerja perawat dapat menentukan baik atau tidaknya pelayanan di sebuah rumah sakit karena perawat melakukan interaksi langsung terhadap pasien.

Memiliki perawat yang kompeten dapat meningkatkan kinerja lembaga tersebut dan dapat meminimalkan kesalahan dalam melakukan prosedur kesehatan. Hasil studi pendahuluan dengan melakukan wawancara pada perawat secara acak diperoleh informasi bahwa perawat yang telah menjadi karyawan tetap mengalami beberapa masalah yang mempengaruhi kinerjanya seperti kualitas dan kuantitas kerja yang menurun, ketepatan waktu dan keefektifan yang kurang saat bekerja serta kemandirian dalam melakukan tugas.

Perawat yang berstatus kontrak belum terlalu mengalami masalah saat bekerja karena masih beradaptasi dengan lingkungan organisasi dan mengenal tugas-tugas yang menjadi tanggungjawabnya. Beberapa kinerja perawat masih berpengaruh terhadap hal-hal tertentu dalam organisasi. Hal-hal yang mempengaruhi kinerja perawat saat bekerja melayani pasien, seperti mengalami kejenuhan saat bekerja dan perubahan emosional perawat saat menghadapi pasien yang kurang kooperatif atau dalam bekerja dengan sesama rekan yang tidak disukai. Melakukan tugas sekedarnya dan tidak menyelesaikan tugas secara sungguhsungguh dapat memberikan dampak yang kurang baik terhadap pasien dan rumah sakit. Karena kesalahan yang dilakukan akan berdampak terhadap pasien dan instansi sendiri. Hal-hal seperti ini harus ditanggulangi oleh pihak manajemen agar 
tidak mempengaruhi kinerja perawat secara keseluruhan. Usaha untuk meningkatkan kinerja perawat, diantaranya dapat dilakukan dengan memperhatikan stres kerja. Indikator rendahnya kinerja perawat RSD Mangusada disajikan pada Tabel 1 sebagai berikut.

Tabel 1.

Indikator Rendahnya Kinerja Perawat Tetap RSD Mangusada

\begin{tabular}{cl}
\hline Indikator Kinerja & \multicolumn{1}{c}{ Faktor Kinerja Rendah } \\
\hline Kualitas Kerja & $\begin{array}{l}\text { Terdapat beberapa perawat yang kurang memperhatikan } \\
\text { standar kerja dalam menyelesaikan tugas }\end{array}$ \\
\hline Kuantitas & $\begin{array}{l}\text { Beberapa perawat tidak menyelesaikan tugas-tugas yang } \\
\text { menjadi tanggung jawabnya }\end{array}$ \\
\hline Ketepatan waktu & $\begin{array}{l}\text { Terdapat beberapa perawat yang belum kembali bertugas } \\
\text { saat jam istirahat telah selesai }\end{array}$ \\
\hline Efektivitas & $\begin{array}{l}\text { Perawat masih belum bekerja sama secara efektif dengan } \\
\text { memanfaatkan sumber daya yang ada }\end{array}$ \\
\hline Kemandirian & $\begin{array}{l}\text { Terdapat perawat yang belum bisa menyelesaikan } \\
\text { tugasnya secara mandiri }\end{array}$ \\
\hline
\end{tabular}

Sumber : RSD Mangusada, 2018.

Usaha untuk meningkatkan kinerja diantaranya dengan memperhatikan stres kerja. Menurut studi pendahuluan yang dilakukan, stres yang muncul pada perawat disebabkan oleh lingkungan non fisik rumah sakit yang kurang baik seperti pada saat berinteraksi dengan pasien dan rekan kerja. Perawat merasa stres jika menghadapi pasien yang kurang kooperatif saat bekerja. Stres pada perawat disini muncul jika ada rekan kerja yang kurang bisa kerjasama dalam melakukan pekerjaan.

Stres merupakan suatu kondisi keadaan seseorang mengalami ketegangan karena adanya kondisi yang mempengaruhinya, kondisi tersebut dapat diperoleh dari dalam diri seseorang maupun lingkungan diluar diri seseorang. Stres dapat menimbulkan dampak yang negatif terhadap keadaan psikologis dan biologis bagi karyawan. 
Menurut Robbins (2008:368) stres adalah suatu kondisi dinamis dimana seorang individu dihadapkan pada peluang, tuntutan, atau sumber daya yang terkait dengan apa yang dihasratkan oleh individu itu dan yang hasilnya dipandang tidak pasti dan penting. Sedangkan definisi stres menurut Luthans (2006:441) adalah suatu tanggapan dalam menyesuaikan diri yang dipengaruhi oleh perbedaan individu dan proses psikologis, sebagai konsekuensi dari tindakan lingkungan, situasi atau peristiwa yang terlalu banyak mengadakan tuntutan psikologis dan fisik seseorang. Stres kerja dapat dipengaruhi oleh masalah dalam organisasi. Menurut Rice (2005:141)seseorang dapat dikategorikan mengalami stres kerja jika urusan stres yang dialami melibatkan juga pihak organisasi tempat individu bekerja.

Faktor lain yang mempengaruhi kinerja adalah burnout. Menurut studi pendahuluan yang dilakukan, kelelahan kerja atau burnout pada perawat disebabkan oleh rasa jenuh yang dialami perawat karena merasakan pekerjaan yang dilakukan sehari-hari adalah hal yang monoton. Dengan terbiasa melakukan sesuatu secara berulang dapat menyebabkan kejenuhan bagi seseorang. Perawat merasa kurang dihargai oleh atasan atau rekan kerja karena masih terdapat jarak yang signifikan antara atasan dengan bawahan. Karena itu perawat merasa lelah dan menimbulkan burnout bagi perawat.

Menurut Maslach \& Leiter (2008) kelelahan kerja (Burnout) ini cenderung dirasakan pada karyawan dengan lama kerja, karena semakin lama karyawan bekerja ia akan semakin terbiasa dengan pekerjaannya, sedangkan untuk karyawan yang baru memulai menguasai pekerjaannya, ia mulai belajar menguasai pekerjaan secara tidak langsung. Burnout adalah sindrom psikologis yang disebabkan adanya rasa kelelahan secara fisik, mental, maupun emosional, yang menyebabkan 
seseorang terganggu dan terjadi penurunan pencapaian prestasi pribadi. Pekerja yang terkena kelelahan kerja (burnout) mengalami kelelahan mental, kehilangan komitmen, kelelahan emosional, dan juga mengalami penurunan motivasi seiring dengan berjalannya waktu (Bhanugopan \& Fish, 2006). Ketidaksesuaian apa yang diberikan perusahaan kepada karyawan, seperti adanya persaingan yang tidak sehat antar sesama karyawan serta kurang dukungan dari atasan. Hal inilah yang menimbulkan gejala burnout dalam diri karyawan (Yanuar \& Mulyadi, 2010)

Faktor yang juga mempengaruhi kinerja adalah motivasi. Motivasi disebutkan sebagai salah satu faktor yang mempengaruhi kinerja. Perawat di RSD Mangusada sangat mengharapkan adanya motivasi dalam bentuk materi atau non materi karena akan berpengaruh pada kinerja mereka. Karena tugas yang banyak dikerjakan oleh perawat, motivasi merupakan hal yang mampu membangkitkan semangat kerja. Hal tersebut menjadi pemacu perawat dalam melaksanakan tugastugasnya di rumah sakit. Manajer dalam level apapun akan senantiasa dituntut untuk berbuat sesuatu yang dapat mempengaruhi orang-orang yang dipimpinnya termotivasi, sehingga anggota organisasi tersebut dapat memberikan kinerja yang memuaskan, karena mereka melakukan tugasnya dengan perasaan gembira, dalam suasana kegairahan yang tinggi, dan tidak tertekan (Ardana, Mujiati, \& Sriathi, 2009)

Menurut Mangkunegara (2005:61) menyatakan bahwa motivasi terbentuk dari sikap (attitude) karyawan dalam menghadapi situasi kerja di perusahaan (situation). Motivasi merupakan kondisi atau energi yang menggerakkan diri karyawan yang terarah atau tertuju untuk mencapai tujuan organisasi. Sikap mental 
karyawan yang pro dan positif terhadap situasi kerja itulah yang memperkuat motivasi kerjanya untuk mencapai kinerja yang maksimal. Motivasi adalah sebuah kondisi atau tindakan yang digunakan seseorang sebagai dorongan untuk menciptakan atau melakukan kegiatan atau pekerjaan secara maksimal.untuk berbuat atau berproduksi (Murty \& Hudiwinarsih, 2012)

Penelitian ini didukung oleh Mohtaram (2015) dalam penelitiannya tentang disposisional stress kerja dan kepuasan kerja terhadap kinerja karyawan menunjukan pengaruh yang negatif. Selain itu Wartono (2017) tentang pengaruh stres kerja terhadap kinerja karyawan juga memiliki pengaruh negatif signifikan. Menurut penelitian Endri \& Sudibia (2015) burnout berpengaruh signifikan negatif terhadap kinerja karyawan. Menurut Adnyaswari (2017) tentang pengaruh dukungan sosial dan burnout menunjukan pengaruh negatif signifikan terhadap kinerja perawat rawat inap di RSUP Sanglah.

Hummayoun (2015) dalam penelitiannya tentang dampak burnout terhadap kinerja karyawan pada industri perbankan menunjukan adanya pengaruh yang negatif signifikan. Almustofa (2014), Larasati \& Gilang (2014) yang menunjukkan motivasi kerja berpengaruh positif dan signifikan terhadap kinerja karyawan. Menurut Widnyana, Sintaasih, \& Riana (2016) juga menunjukan hasil yang positif signifikan terhadap kinerja karyawan.

Tempat penelitian ini adalah RSD Mangusada dengan perawat yang berstatus karyawan tetap sebagai subyek penelitian. RSD Mangusada hadir untuk mengakomodir pelayanan kesehatan dengan senantiasa berpegang pada prinsip melayani dengan hati. RSD Mangusada sangat membutuhkan kinerja perawat yang 
baik untuk meningkatkan kualitas pelayanan, karena dengan memiliki tanggung jawab yang tinggi, tujuan yang realitas, rencana kerja yang menyeluruh, berani mengambil risiko yang dihadapi, maka kinerja dalam pelayanan akan meningkat.

Berdasarkan latar belakang yang dikemukakan diatas, maka dapatdirumuskan permasalahan sebagai berilkut 1) Bagaimana pengaruh stres kerja terhadap kinerja perawat RSD Mangusada? 2) Bagaimana pengaruh kelelahan kerja (burnout) terhadap kinerja perawat RSD Mangusada? 3) Bagaimana pengaruh motivasi kerja terhadap kinerja perawat RSD Mangusada?

Berdasarkan latar belakang dan rumusan masalah yang ada, maka penelitian ini dilakukan dengan tujuan: 1) Untuk menganalisis pengaruh stres kerja terhadap kinerja perawat RSD Mangusada 2) Untuk menganalisis pengaruh kelelahan kerja (burnout) terhadap kinerja perawat RSD Mangusada. 3) Untuk menganalisis pengaruh motivasi kerja terhadap kinerja perawat RSD Mangusada.

Penelitian ini diharapkan mampu memberikan bukti empiris dalam bidang ilmu manajemen sumber daya manusia, khususnya mengenai stres kerja, kelelahan kerja (burnout), motivasi kerja dan kinerja.

Penelitian ini diharapkan bisa menjadi referensi bagi RSD Mangusada sebagai bahan pertimbangan dan masukan mengenai sejauh mana pengaruh stres kerja, kelelahan kerja (burnout), motivasi kerja terhadap kinerja perawat. Diharapkan penelitian ini dapat menyumbangkan pemikiran dan menjadi acuan dalam menentukan kebijakan strategi pengelolaan dan peningkatan sumber daya manusia di masa mendatang. 
Menurut Robbins (2008:577) stres adalah suatu kondisi dinamis yang didalamnya seorang individu di konfrotasikan dengan suatu peluang, kendala, atau tuntutan yang dikaitkan dengan apa yang sangat diinginkan dan hasilnya di persepsikan sebagai tidak pasti dan penting. Penelitian Chandra (2014) menunjukkan bahwa stres kerja secara parsial mempunyai pengaruh yang negatif signifikan terhadap kinerja di P.T. Lie Fung Surabaya. Menurut penelitian Mohtaram (2015) menunjukkan stres kerja berpengaruh negatif terhadap kinerja. Menurut penelitian Satriyo (2014) dan Hera \& Hasmin (2016) menunjukan hasil negatif signifikan terhdap kinerja. Wartono (2017) yang meneliti tentang pengaruh stres kerja terhadap kinerja karyawan (studi pada karyawan majalah mother and baby) juga menunjukan pengaruh yang negatif signifikan. Disamping itu penelitian Widyastuti (2015) dan Julvia (2016) juga menunjukan hal yang sama yaitu stres kerja berpengaruh negatif signifikan terhadap kinerja. Pengaruh stres kerja terhadap kinerja adalah negatif, artinya bahwa ketika stres kerja rendah maka kinerja tinggi, dan demikian pula sebaliknya.

\section{$\mathrm{H}_{1}$ : Stres Kerja berpengaruh negatif dan signifikan terhadap kinerja perawat}

Maslach \& Leiter (2008) menyatakan bahwa burnout merupakan reaksi emosi negatif yang terjadi di lingkungan kerja, ketika individu tersebut mengalami stres yang berkepanjangan. Burnout merupakan stres kerja dan beban kerja yang paling umum, gejala khusus pada kejenuhan kerja ini antara lain kebosanan, depresi, pesimisme, kurang konsentrasi, kualitas kerja buruk, ketidakpuasan, keabsenan, dan kesakitan atau penyakit. Menurut penelitian Erdilek, Tezergil, \& Kose (2014) 
dalam penelitiannya terhadap burnout, menunjukkan pengaruh yang negatif signifikan terhadap kinerja. Menurut Hummayoun (2015) yang meneliti dampak burnout terhadap kinerja karyawan pada industri perbankan menunjukan adanya pengaruh yang negatif signifikan. Adnyaswari (2017) yang meneliti tentang pengaruh burnout terhadap kinerja perawat rawat inap di RSUP Sanglah memberikan pengaruh negatif signifikan terhadap kinerja perawat.

\section{$\mathrm{H}_{2}$ : Kelelahan Kerja (Burnout) berpengaruh negatif dan signifikan terhadap kinerja perawat}

Menurut Maslow (2010) motivasi merupakan kekuatan atau energi seseorang yang dapat menimbulkan tingkat persistensi dan entusiasmenya dalam melaksanakan suatu kegiatan, baik bersumber dari dalam diri individu atau luar individu. Dalam penelitian Amianti \& Supriyanto (2012) menyatakan motivasi kerja memiliki pengaruh signifikan positif dengan kinerja karyawan, karena apabila motivasi kerja meningkat maka secara tidak langsung kinerja karyawan pun akan meningkat. Penelitian Larasati \& Gilang (2014) juga menunjukan pengaruh signifikan positif dalam penelitiannya tentang pengaruh motivasi kerja terhadap kinerja karyawan wilayah telkom Jabar barat utara (witel bekasi). Menurut penelitian Widnyana, Sintaasih, \& Riana (2016) dan Muliani, Sudibia, \& Sintaasih (2017) juga menunjukan hasil yang sebanding bahwa motivasi kerja berpengaruh positif terhadap kinerja.

\section{$\mathrm{H}_{3}$ : Motivasi berpengaruh positif dan signifikan terhadap kinerja perawat.}




\section{METODE PENELITIAN}

Penelitian ini dilakukan dengan menggunakan metode asosiatif yang digunakan untuk mengetahui pengaruh dua variabel atau lebih. Desain penelitian disusun untuk memberikan gambaran informasi. Penelitian ini bertujuan untuk menganalisis pengaruh stres kerja, kelelahan kerja (burnout), dan motivasi kerja terhadap kinerja perawat pada RSD Mangusada.

Penelitian ini dilakukan pada RSD Mangusada yang beralamat di Jalan Raya Kapal, Mengwi, Badung - Bali. Lokasi ini dipilih karena ditemukan masalahmasalah terkait kinerja perawat yang diduga dipengaruhi oleh stres kerja, kelelahan kerja (burnout), dan motivasi kerja.

Objek penelitian ini adalah stres kerja (X1), kelelahan kerja (burnout) (X2), dan motivasi kerja (X3) terhadap kinerja perawat (Y). Variabel terikat (Dependent Variable) yaitu variabel yang dipengaruhi atau yang menjadi akibat, karena adanya variabel bebas. Variabel terikat dalam penelitian ini adalah Kinerja Perawat (Y).Variabel bebas (Independent Variable) Yaitu variabel yang mempengaruhi atau yang menjadi sebab perubahannya atau timbulnya variabel terikat. Variabel bebas dalam penelitian ini adalah stres kerja (X1), kelelahan kerja (burnout) (X2), dan motivasi kerja (X3).

Kinerja adalah hasil kerja yang dilakukan seorang perawat selama periode tertentu dibandingkan dengan kemungkinan, misalnya standar, target, sasaran atau kinerja yang telah ditentukan terlebih dahulu dan telah disepakati bersama. Menurut 
Robbins (2008:260) Indikator yang dapat digunakan untuk kinerja adalah 1) Kualitas kerja yang dapat diukur dari persepsi perawat terhadap kemampuan dalam memenuhi standar kerja yang ditentukan oleh rumah sakit. 2) Kuantitas merupakan persepsi karyawan terhadap jumlah pasien yang mampu ditangani dalam bekerja. 3) Ketepatan waktu merupakan persepsi perawat terhadap tingkat aktivitas yang mampu diselesaikan pada awal waktu yang dinyatakan. 4) Efektivitas merupakan persepsi perawat terhadap tingkat penggunaan sumber daya organisasi, salah satunya dalam menggunakan alat medis. 5) Kemandirian merupakan persepsi perawat mempunyai rasa mandiri dalam mengerjakan semua tugas dalam bekerja.

Stres kerja adalah kondisi ketegangan perawat secara emosional yang menciptakan adanya ketidakseimbangan fisik dan psikis yang mempengaruhi emosi, proses berpikir, dan kondisi seorang karyawan. Menurut Robbins (2008:370), indikator dalam stres kerja yaitu Lingkungan, Organisasi dan Individu.

Burnout merupakan kelelahan kerja yang dialami perawat karena kelelahan mental, kelelahan emosional, dan juga mengalami penurunan motivasi seiring dengan berjalannya waktu dalam menjalani pekerjaan. Menurut Maslach \& Leiter (2008) burnout mempunyai tiga indikator yaitu 1) Kelelahan Emosional (Emotional exhaustion) 2) Depersonalisasi (Depersonalization) 3) Penurunan Pencapaian Prestasi Pribadi.

Motivasi adalah suatu perangsang keinginan daya gerak kemauan bekerja seorang perawat untuk memuaskan kubutuhan individunya, setiap motif mempunyai tujuan tertentu yang ingin dicapai. Indikator motivasi kerja adalah Motivasi internal dan Motivasi eksternal 
Data kuantitatif, yaitu data yang dalam bentuk angka. Data yang diperlukan dalam penelitian ini adalah hasil jawaban kuesioner yang menghasilkan penilaian terhadap stres kerja, kelelahan kerja (burnout) dan motivasi kerja terhadap perawat di RSD Mangusada.

Data kualitatif, yaitu data yang berbentuk kata, penjelasan, skema dan gambar. Data yang digunakan dalam penelitian ini adalah skema yang terkait dengan variabel yang diteliti serta hasil wawancara terhadap perawat.

Data dalam penelitian ini diperoleh dari jawaban responden atas pertanyaan yang diajukan oleh peneliti dalam bentuk kuesioner seperti data stres kerja, kelelahan kerja (burnout), motivasi kerja serta kinerja perawat.

Populasi penelitian ini adalah seluruh perawat tetap pada RSD Mangusada yang berjumlah 186 orang. Besarnya sampel dalam penelitian ini ditentukan dengan menggunakan rumus slovin yang memperoleh jumlah 127 orang. Metode pengambilan sampel yang digunakan dalam penelitian ini adalah propotionate stratified random sampling.

Tabel 2. Jumlah populasi dan sampel perawat tetap RSD Mangusada

\begin{tabular}{clccc}
\hline No. & Bagian-bagian keperawatan & Populasi & Fi & Sampel \\
\hline 1. & Poliklinik anak & 2 & $(2: 168) \times 127=1,37$ & 1 \\
2. & Poliklinik bedah & 4 & $(4: 168) \times 127=2,73$ & 3 \\
3. & Poliklinik interna & 4 & $(4: 168) \times 127=2,73$ & 3 \\
4. & Poliklinik kulit \& kelamin & 2 & $(2: 168) \times 127=1,37$ & 1 \\
5. & Poliklinik THT & 2 & $(2: 168) \times 127=1,37$ & 1 \\
6. & Poliklinik mata & 3 & $(3: 168) \times 127=2,05$ & 2 \\
7. & Poliklinik syaraf & 3 & $(3: 168) \times 127=2,05$ & 2 \\
8. & Poliklinik VCT & 2 & $(2: 168) \times 127=1,37$ & 1 \\
9. & Poliklinik Anestesi & 3 & $(3: 168) \times 127=2,05$ & 2 \\
10. & Poliklinik Gigi & 3 & $(3: 168) \times 127=2,05$ & 2 \\
11. & Poliklinik Jiwa & 2 & $(2: 168) \times 127=1,37$ & 1 \\
12. & Poliklinik Filter & 1 & $(1: 168) \times 127=0,68$ & 1 \\
13. & Poliklinik Jantung & 2 & $(2: 168) \times 127=1,37$ & 1 \\
14. & Poliklinik Bedah Orto, Syaraf & 2 & $(2: 168) \times 127=1,37$ & 1 \\
15. & Poliklinik Bedah Digestif & 1 & $(1: 168) \times 127=0,68$ & 1 \\
16. & Instalasi Gawat Darurat & 13 & $(13: 168) \times 127=8,88$ & 9 \\
\hline
\end{tabular}




\begin{tabular}{|c|c|c|c|c|}
\hline 17. & Ruang VK Kebidanan & 3 & $(3: 168) \times 127=2,05$ & 2 \\
\hline 18. & Ruang Operasi (OK) & 28 & $(28: 168) \times 127=9,12$ & 20 \\
\hline 19. & Ruang HD & 11 & $(11: 168) \times 127=7,51$ & 8 \\
\hline 20. & Ruang Endoscopi & 2 & $(2: 168) \times 127=1,37$ & 1 \\
\hline 21. & Ruang ICU (Panyembrama) & 11 & $(11: 168) \times 127=7,51$ & 8 \\
\hline 22. & Ruang ICCU & 10 & $(10: 168) \times 127=6,83$ & 7 \\
\hline 23. & Ruang HCU (Puspanjali) & 9 & $(9: 168) \times 127=6,15$ & 6 \\
\hline 24. & Ruang Janger & 12 & $(12: 168) \times 127=8,19$ & 9 \\
\hline 25 . & Ruang Oleg & 10 & $(10: 168) \times 127=6,83$ & 7 \\
\hline 26. & Ruang Cilinaya & 3 & $(3: 168) \times 127=2,05$ & 2 \\
\hline 27. & Ruang PERI/NICU (Pendet) & 6 & $(6: 168) \times 127=4,10$ & 4 \\
\hline 28. & Ruang Kecak & 5 & $(5: 168) \times 127=3,41$ & 3 \\
\hline 29. & Poliklinik Paviliun & 5 & $(5: 168) \times 127=3,41$ & 3 \\
\hline 30. & Rawat Inap Paviliun Lantai 2 & 7 & $(7: 168) \times 127=4,78$ & 5 \\
\hline 31. & Rawat Inap Paviliun Lantai 3 & 7 & $(7: 168) \times 127=4,78$ & 5 \\
\hline 32. & Ruang OK Paviliun & 5 & $(5: 168) \times 127=3,41$ & 3 \\
\hline 33. & Ruang HCU Paviliun & 2 & $(2: 168) \times 127=1,37$ & 1 \\
\hline 34. & Admision & 1 & $(1: 168) \times 127=0,68$ & 1 \\
\hline & Jumlah & 186 & & 127 \\
\hline
\end{tabular}

Sumber : RSD Mangusada, 2018

Untuk memperoleh data, penelitian ini menggunakan teknik pengumpulan data dengan menggunakan beberapa metode seperti wawancara dan kuesioner. Skala pengukuruan data yang digunakan dalam penelitian yaitu skala likert.

\section{HASIL DAN PEMBAHASAN}

Penelitian ini menggunakan propotionate stratified random sampling dan seluruh populasi diseleksi kembali dengan menggunakan rumus slovin, sehingga 186 perawat tetap diseleksi menjadi 127 perawat tetap sebagai sampel.

Sebagian besar berjenis kelamin perempuan sebanyak 83 orang dengan persentase sebesar 65,36 persen. Sedangkan, untuk responden berjenis kelamin laki-laki sebanyak 44 orang dengan persentase 34,64 persen. Artinya sebagian besar perawat tetap RSD Mangusada mempekerjakan tenaga perempuan. Hal ini menunjukkan sebagian besar karyawan yang diperlukan untuk bidangnya adalah 
tenaga kerja perempuan karena perawat RSD Mangusada mengutamakan pelayanan dengan kasih sayang dan ketelitian.

Sebagian besar responden berusia diantara 26-30 tahun dengan persentase sebesar 48,82 persen. Sedangkan untuk kelompok usia terendah yaitu 41-45 tahun dengan persentase sebesar 3,94 persen. Ini artinya RSD Mangusada lebih banyak mengangkat perawat yang sudah memliki pengalaman kerja yang cukup untuk menjadi perawat tetap.Sebagian besar responden berdasarkan pendidikan terakhirnya adalah D3 sebanyak 101 orang dengan persentase 79,53 persen. Sedangkan kelompok pendidikan terakhir paling kecil dimiliki oleh responden adalah D4 sebanyak 4 orang dengan persentase 3,15 persen. Ini artinya kebanyakan posisi perawat tetap di RSD Mangusada adalah tamatan Diploma yang lebih mengutamakan praktek dalam mengerjakan tugas perawat.

Sebagian besar responden memiliki masa kerja tiga tahun sebanyak 42 orang dengan persentase 33,07 persen. Sedangkan yang memiliki masa kerja empat tahun sebanyak 39 orang dengan persentase sebesar 30,71 persen. Perawat yang memiliki masa kerja lima tahun sebanyak 35 orang dengan persentase sebesar 27,56 persen. Terakhir yang memiliki masa kerja enam tahun sebanyak 11 orang dengan persentase sebesar 8,66 persen. Ini artinya RSD Mangusada memiliki perawat tetap dengan masa kerja dominan 3 tahun karena sudah dirasa cukup berpengalaman menjadi perawat tetap.

Tabel 3.

Hasil Uji Validitas

\begin{tabular}{cccc}
\hline Variabel & Indikator & Pearson Correlation & Keterangan \\
\hline Stres Kerja & $\mathrm{X} 1.1$ & 0,814 & Valid \\
\cline { 2 - 4 }$(\mathrm{X} 1)$ & $\mathrm{X} 1.2$ & 0,483 & Valid \\
\cline { 2 - 4 } & $\mathrm{X} 1.3$ & 0,715 & Valid \\
\hline Kelelahan Kerja & $\mathrm{X} 2.1$ & 0,428 & Valid \\
\hline
\end{tabular}




\begin{tabular}{cccc}
\hline \multirow{2}{*}{$(\mathrm{X} 2)$} & $\mathrm{X} 2.2$ & 0,776 & Valid \\
\cline { 2 - 4 } & $\mathrm{X} 2.3$ & 0,729 & Valid \\
\hline Motivasi Kerja & $\mathrm{X} 3.1$ & 0,611 & Valid \\
\cline { 2 - 4 }$(\mathrm{X} 3)$ & $\mathrm{X} 3.2$ & 0,647 & Valid \\
\cline { 2 - 4 } & $\mathrm{X} 3.3$ & 0,795 & Valid \\
\cline { 2 - 4 } & $\mathrm{X} 3.4$ & 0,745 & Valid \\
\cline { 2 - 4 } & $\mathrm{X} 3.5$ & 0,797 & Valid \\
\hline Kinerja & Y.1 & 0,537 & Valid \\
\cline { 2 - 4 }$($ Y) & Y.2 & 0,480 & Valid \\
\cline { 2 - 4 } & Y.3 & 0,728 & Valid \\
\cline { 2 - 4 } & Y.4 & 0,727 & Valid \\
\hline
\end{tabular}

Sumber : Data Diolah, 2018

Hasil uji validitas menunjukkan bahwa seluruh instrumen penelitian yang digunakan untuk mengukur variabel stres kerja, kelelahan kerja, motivasi kerja dan kinerja memiliki nilai koefisien korelasi dengan skor total seluruh item pernyataan lebih besar dari 0,3. Hal ini menunjukkan bahwa butir-butir pernyataan dalam instrumen penelitian tersebut valid dan layak digunakan sebagai instrumen penelitian.

\section{Tabel 4}

Hasil Uji Reliabilitas

\begin{tabular}{ccc}
\hline Variabel & Cronbach's Alpha & Keterangan \\
\hline $\begin{array}{c}\text { Stres Kerja } \\
\text { (X1) }\end{array}$ & 0,773 & Reliabel \\
Kelelahan Kerja & & Reliabel \\
(X2) & 0,920 & \\
\hline $\begin{array}{c}\text { Motivasi Kerja } \\
\text { (X3) }\end{array}$ & 0,768 & Reliabel \\
\hline $\begin{array}{c}\text { Kinerja } \\
\text { (Y) }\end{array}$ & 0,625 & Reliabel \\
\hline
\end{tabular}

Sumber : Data Diolah, 2018

Hasil uji reliabilitas menunjukkan bahwa seluruh instrumen penelitian yaitu stres kerja, kelelahan kerja, motivasi kerja dan kinerja memiliki koefisien Cronbach's Alpha lebih dari 0,60. Hal ini dapat dikatakan bahwa seluruh variabel telah memenuhi syarat reliabilitas atau kehandalan sehingga dapat digunakan untuk melakukan penelitian. 
Tabel 5.

Deskripsi Jawaban Responden Terhadap Kinerja

\begin{tabular}{|c|c|c|c|c|c|c|c|c|}
\hline \multirow[t]{2}{*}{ No } & \multirow[t]{2}{*}{ Pernyataan } & \multicolumn{5}{|c|}{ Frekuensi Jawaban Responden } & \multirow[t]{2}{*}{ Rata-Rata } & \multirow[t]{2}{*}{ Kriteria } \\
\hline & & STS & TS & CS & $\mathbf{S}$ & SS & & \\
\hline 1. & $\begin{array}{l}\text { Saya melakukan } \\
\text { pekerjaan sesuai standar } \\
\text { yang ditentukan } \\
\text { (Y1.1) }\end{array}$ & 0 & 0 & 0 & 53 & 74 & 4,58 & Sangat Baik \\
\hline 2. & $\begin{array}{l}\text { Saya mampu melayani } \\
\text { setiap pasien yang } \\
\text { ditugaskan ke saya } \\
(\mathrm{Y} 1.2)\end{array}$ & 0 & 0 & 0 & 25 & 102 & 4,80 & Sangat Baik \\
\hline 3. & $\begin{array}{l}\text { Saya tepat waktu dalam } \\
\text { bekerja } \\
\text { (Y1.3) }\end{array}$ & 0 & 5 & 58 & 52 & 12 & 3,56 & Baik \\
\hline 4. & $\begin{array}{l}\text { Saya mampu } \\
\text { menggunakan peralatan } \\
\text { medis saat bekerja } \\
\text { (Y1.4) }\end{array}$ & 0 & 7 & 54 & 53 & 13 & 3,57 & Baik \\
\hline 5. & $\begin{array}{l}\text { Saya mampu melakukan } \\
\text { tugas secara mandiri } \\
\text { (Y1.5) }\end{array}$ & 1 & 5 & 56 & 47 & 18 & 3,60 & Baik \\
\hline & Rata-rata keselur & $\operatorname{aan} v$ & iabe & Kine & & & 4,02 & Baik \\
\hline
\end{tabular}
Sumber : Data Diolah, 2018

Kinerja perawat secara keseluruhan adalah baik, hal ini dapat dilihat dari keseluruhan rata-rata nilai kinerja yaitu 4,02. Terdapat dua pernyataan yang mendapatkan nilai di atas rata-rata.

Nilai rata-rata tertinggi sebesar 4,80 pada pernyataan "Saya mampu melayani setiap pasien yang ditugaskan ke saya". Ini berarti bahwa perawat merasa mampu dalam melayani setiap pasien yang ditugaskan kepadanya. Selanjutnya terdapat dalam pernyataan "Saya melakukan pekerjaan sesuai standar yang ditentukan" dengan nilai rata-rata sebesar 4,58. Hal ini menunjukkan bahwa perawat sangat memperhatikan standar kerja dalam melakukan tugas. Sedangkan terdapat tiga pernyataan yang mempunyai nilai di bawah rata-rata.

Nilai rata-rata terendah yaitu pada pernyataan "Saya tepat waktu dalam bekerja" dengan nilai rata-rata 3,56. Dalam pernyataan "Saya mampu 
menggunakan peralatan medis saat bekerja” dengan nilai rata-rata 3,57 dan dalam pernyataan "Saya mampu melakukan tugas secara mandiri” dengan rata-rata nilai sebesar 3,60. Hal ini menunjukkan perawat sudah mampu bekerja dengan tepat waktu, mampu menggunakan peralatan medis dengan baik dan mampu melaksanakan tugas secara mandiri. Walaupun hasil keseluruhan menyatakan baik, namun terdapat beberapa responden yang menjawab cukup setuju.

Menurut hasil observasi yang dilakukan, responden yang menjawab cukup setuju lebih mengarah kepada pernyataan tidak setuju. Hal tersebut karena ada beberapa faktor mempengaruhi hasil jawaban responden.

Tabel 6.

Deskripsi Jawaban Responden Terhadap Stres Kerja

\begin{tabular}{|c|c|c|c|c|c|c|c|c|}
\hline \multirow[t]{2}{*}{ No } & \multirow[t]{2}{*}{ Pernyataan } & \multicolumn{5}{|c|}{ Frekuensi Jawaban Responden } & \multirow{2}{*}{$\begin{array}{l}\text { Rata- } \\
\text { Rata }\end{array}$} & \multirow[t]{2}{*}{ Kriteria } \\
\hline & & STS & TS & CS & $\mathbf{S}$ & SS & & \\
\hline 1. & $\begin{array}{l}\text { Saya kurang nyaman } \\
\text { dengan beberapa rekan } \\
\text { kerja di kantor (X1.1) }\end{array}$ & 0 & 0 & 14 & 73 & 40 & 4,20 & Tinggi \\
\hline 2. & $\begin{array}{l}\text { Saya merasa } \\
\text { pembagian jadwal kerja } \\
\text { yang dibebankan } \\
\text { kurang sesuai } \\
\text { (X1.2) }\end{array}$ & 0 & 0 & 25 & 68 & 34 & 4,07 & Tinggi \\
\hline 3. & $\begin{array}{l}\text { Saya merasa cemas saat } \\
\text { bekerja karena ada } \\
\text { masalah keluarga } \\
\text { (X1.3) }\end{array}$ & 0 & 0 & 11 & 73 & 43 & 4,25 & Sangat Tinggi \\
\hline & Rata-rata keselur & ian va & abel & res I & & & 4,18 & Tinggi \\
\hline
\end{tabular}

Sumber : Data Diolah, 2018

Stress kerja secara keseluruhan adalah tinggi. Hal ini dapat dilihat dari keseluruhan rata-rata nilai Stres Kerja yaitu 4,18. Terdapat dua pernyataan yang memiliki nilai di atas rata-rata yaitu dalam pernyataan "Saya merasa cemas saat bekerja karena ada masalah keluarga" dengan nilai rata-rata 4,25. Hal ini menunjukkan bahwa perawat merasa cemas saat bekerja jika ada masalah dalam keluarga. 
Pernyataan "Saya kurang nyaman dengan beberapa rekan kerja di kantor" dengan nilai rata-rata sebesar 4,20. Hal ini menunjukan bahwa perawat kurang nyaman dengan beberapa rekan yang diajak bekerja. Sedangkan terdapat pernyataan yang memiliki nilai dibawah rata-rata. Terdapat dalam pernyataan "Saya merasa pembagian jadwal kerja yang dibebankan kurang sesuai" dengan nilai rata-rata sebesar 4,20. Hal ini menunjukkan bahwa perawat merasa pembagian jadwal kerja kurang sesuai.

Tabel 7.

Deskripsi Jawaban Responden Terhadap Kelelahan Kerja

\begin{tabular}{|c|c|c|c|c|c|c|c|c|}
\hline \multirow[t]{2}{*}{ No } & \multirow[t]{2}{*}{ Pernyataan } & \multicolumn{5}{|c|}{ Frekuensi Jawaban Responden } & \multirow{2}{*}{$\begin{array}{l}\text { Rata- } \\
\text { Rata }\end{array}$} & \multirow[t]{2}{*}{ Kriteria } \\
\hline & & STS & TS & CS & $\mathbf{S}$ & SS & & \\
\hline 1. & $\begin{array}{l}\text { Saya merasa lelah } \\
\text { karena melayani pasien } \\
\text { yang banyak } \\
(\mathrm{X} 2.1)\end{array}$ & 0 & 3 & 39 & 62 & 23 & 3,83 & Tinggi \\
\hline 2. & $\begin{array}{l}\text { Saya merasa sinis jika } \\
\text { rekan kerja } \\
\text { membicarakan saya } \\
(\mathrm{X} 2.2)\end{array}$ & 0 & 2 & 34 & 64 & 27 & 3,91 & Tinggi \\
\hline 3. & $\begin{array}{l}\text { Saya merasa monoton } \\
\text { dalam melakukan } \\
\text { pekerjaan } \\
(\mathrm{X} 2.3)\end{array}$ & 0 & 1 & 41 & 62 & 23 & 3,84 & Tinggi \\
\hline \multicolumn{7}{|c|}{ Rata-rata keseluruhan variabel Kelelahan Kerja } & 3,86 & Tinggi \\
\hline
\end{tabular}

Sumber : Data Diolah, 2018

Kelelahan kerja secara keseluruhan adalah tinggi. Hal ini dapat dilihat dari keseluruhan rata-rata nilai Kelelahan Kerja yaitu 3,86. Nilai diatas rata-rata terdapat pada pernyataan "Saya merasa sinis jika rekan kerja membicarakan saya" dengan nilai rata-rata sebesar 3,91 . Hal ini menunjukan bahwa perawat merasa sinis jika ada rekan kerja yang sedang membicarakan dirinya.

Terdapat dua dalam pernyataan yang memiliki nilai dibawah rata-rata. Terdapat dalam pernyataan "Saya merasa lelah karena melayani pasien yang 
banyak" dengan nilai rata-rata sebesar 3,83. Hal ini menunjukkan perawat merasa lelah jika melayani pasien yang banyak.

Terdapat dalam pernyataan "Saya merasa monoton dalam melakukan pekerjaan" dengan nilai rata-rata sebesar 3,84. Hal ini menunjukan bahwa perawat merasa pekerjaan yang dilakukannya monoton sehingga memungkinkan membuat perawat merasa bosan dalam bekerja. Hal-hal tersebut harus diperhatikan agar dapat mengurangi kelelahan kerja yang dialami oleh perawat.

Motivasi kerja secara keseluruhan adalah tinggi. Hal ini dapat dilihat dari keseluruhan rata-rata nilai Motivasi Kerja yaitu 3,74. Terdapat tiga pernyataan yang memiliki nilai di atas rata-rata. Nilai diatas rata-rata yang paling tinggi terdapat pada pernyataan "Saya bekerja untuk memenuhi kebutuhan hidup" dengan nilai rata-rata sebesar 3,83. Hal ini menunjukan bahwa perawat termotivasi untuk bekerja karena ada kebutuhan hidup yang harus benar-benar dipenuhi.

Nilai di atas rata-rata terdapat dalam pernyataan "Saya berharap mendapat insentif lebih saat bekerja" dengan nilai rata-rata 3,79 dan dalam pernyataan "Saya senang mendapat pujian atas pekerjaan yang saya lakukan" dengan nilai rata-rata 3,76. Hal ini menunjukkan bahwa perawat termotivasi dengan adanya insentif dan penghargaan berupa pujian sangat bekerja.

Tabel 8.

Deskripsi Jawaban Responden Terhadap Motivasi Kerja

\begin{tabular}{|c|c|c|c|c|c|c|c|c|}
\hline \multirow[t]{2}{*}{ No } & \multirow[t]{2}{*}{ Pernyataan } & \multicolumn{5}{|c|}{ Frekuensi Jawaban Responden } & \multirow{2}{*}{$\begin{array}{l}\text { Rata- } \\
\text { Rata }\end{array}$} & \multirow[t]{2}{*}{ Kriteria } \\
\hline & & STS & TS & CS & $\mathbf{S}$ & SS & & \\
\hline 1. & $\begin{array}{l}\text { Saya melakukan } \\
\text { pekerjaan dengan } \\
\text { penuh tanggung jawab } \\
\text { (X3.1) }\end{array}$ & 1 & 5 & 51 & 51 & 19 & 3,65 & Tinggi \\
\hline
\end{tabular}


2. Saya memperhatikan target saat bekerja (X3.2)

3. Saya bekerja untuk $\begin{array}{llllllll}\text { memenuhi kebutuhan } & 0 & 6 & 38 & 55 & 28 & 3,83 & \text { Tinggi }\end{array}$ hidup (X3.3)

4. Saya senang mendapat pujian atas pekerjaan yang saya lakukan (X3.4)

5. Saya berharap $\begin{array}{lllllllll}\text { mendapat insentif lebih } & 0 & 5 & 44 & 51 & 27 & 3,79 & \text { Tinggi }\end{array}$ saat bekerja (X3.5)

Rumber : Data Diolah, 2018

Ada dua pernyataan yang memiliki nilai di bawah rata-rata. Untuk nilai ratarata terendah terdapat dalam pernyataan "Saya melakukan pekerjaan dengan penuh tanggung jawab" dengan nilai rata-rata sebesar 3,65. Hal ini menunjukan bahwa perawat menjadikan tanggung jawab sebagai sebuah motivasi dalam bekerja, namun masih ada yang kurang termotivasi dengan tanggung jawab yang dimilikinya. Selanjutnya terdapat dalam pernyataan "Saya memperhatikan target saat bekerja" dengan nilai rata-rata 3,66. Walaupun motivasi perawat terlihat sudah bagus tetapi harus dapat dipertahankan agar motivasi perawat bisa semakin tinggi dalam bekerja.

Tabel 9.

Hasil Uji Normalitas

\begin{tabular}{cc}
\hline & Unstandardized Residual \\
\hline $\mathrm{N}$ & 127 \\
Kolmogorov-Smirnov Z & 0,829 \\
Asymp. Sig. (2-tailed) & 0,499 \\
\hline
\end{tabular}
Sumber : Data Diolah, 2018

Hasil uji Normalitas menunjukkan nilai Asymp.Sig (2-tailed) sebesar 0,499 yaitu lebih besar dari 0,05 $(0,499>0,05)$. Dengan demikian dapat dinyatakan bahwa data telah memenuhi syarat normalitas dan terdistribusi normal. 
Tabel 10.

Hasil Uji Multikolinieritas

\begin{tabular}{lcc}
\hline \multicolumn{1}{c}{ Model } & \multicolumn{2}{c}{ Collinearity Statistics } \\
\cline { 2 - 3 } & Tolerance & VIF \\
\hline Stres Kerja & 0,256 & 3,914 \\
Kelelahan Kerja (Burnout) & 0,232 & 4,309 \\
Motivasi Kerja & 0,578 & 1,729 \\
\hline Sumber : Data Diolah, 2018 & &
\end{tabular}

Variable Stres Kerja memiliki tolerance lebih besar dari 0,10 (0,256 > 0,10) dan VIF lebih kecil dari $10(3,914<10)$. Variabel Kelelahan Kerja (Burnout) memiliki tolerance lebih besar dari 0,10 (0,232 > 0,10) dan VIF lebih kecil dari 10 (4,309 < 10). Variabel Perceived Motivasi Kerja memiliki tolerance lebih besar dari $0,10(0,578>0,10)$ dan VIF lebih kecil dari $10(1,729<10)$. Hasil ini mengindikasikan bahwa tidak terdapat gejala multikolinearitas dari model regresi yang dibuat sehingga pada model regresi tidak ditemukan korelasi antar variabel bebas.

Tabel 11. Hasil Uji Heteroskedastisitas

\begin{tabular}{|c|c|c|c|c|c|}
\hline \multirow[t]{2}{*}{ Model } & \multicolumn{2}{|c|}{$\begin{array}{c}\text { Unstandardized } \\
\text { Coefficients }\end{array}$} & \multirow{2}{*}{$\begin{array}{c}\begin{array}{c}\text { Standardized } \\
\text { Coefficients }\end{array} \\
\text { Beta } \\
\end{array}$} & \multirow[t]{2}{*}{$\mathrm{t}$} & \multirow[t]{2}{*}{ Sig. } \\
\hline & $\mathrm{B}$ & Std. Error & & & \\
\hline (Constant) & 0,780 & 0,952 & & 0,820 & 0,414 \\
\hline Stres Kerja & $-0,098$ & 0,098 & $-0,177$ & $-0,998$ & 0,320 \\
\hline $\begin{array}{l}\text { Kelelahan Kerja } \\
\text { (Burnout) }\end{array}$ & 0,087 & 0,094 & 0,172 & 0,925 & 0,357 \\
\hline Motivasi Kerja & 0,017 & 0,028 & 0,071 & 0,602 & 0,548 \\
\hline
\end{tabular}

Hasil signifikansi Stres Kerja lebih besar dari 0,05 (0,320 > 0,05). Besar signifikansi Kelelahan Kerja (Burnout) lebih besar dari $0,05(0,357>0,05)$. Besar signifikansi Motivasi Kerja lebih besar dari 0,05 (0,548 > 0,05). Dengan demikian dapat dinyatakan tidak terjadi heteroskedastisitas 
Tabel 12.

Hasil Analisis Regresi Linier Berganda

\begin{tabular}{|c|c|c|c|c|c|c|}
\hline & \multirow{2}{*}{ Model } & \multicolumn{2}{|c|}{$\begin{array}{c}\text { Unstandardized } \\
\text { Coefficients }\end{array}$} & \multirow{2}{*}{$\begin{array}{c}\text { Standardized } \\
\text { Coefficients }\end{array}$} & \multirow[t]{2}{*}{$\mathrm{T}$} & \multirow[t]{2}{*}{ Sig } \\
\hline & & B & $\begin{array}{l}\text { Std. } \\
\text { Error }\end{array}$ & & & \\
\hline \multirow[t]{4}{*}{1} & (Constant) & 21,257 & 1,680 & & 12,654 & 0,000 \\
\hline & Stres Kerja & $-0,392$ & 0,174 & $-0,238$ & $-2,261$ & 0,026 \\
\hline & $\begin{array}{l}\text { Kelelahan Kerja } \\
\text { (Burnout) }\end{array}$ & $-0,401$ & 0,166 & $-0,267$ & $-2,417$ & 0,017 \\
\hline & Motivasi Kerja & 0,285 & 0,050 & 0,401 & 5,726 & 0,000 \\
\hline
\end{tabular}

Sumber : Data Diolah, 2018

Berdasarkan hasil analisis regresi linier maka didapatkan bahwa nilai koefisien regresi stres kerja (X1) sebesar -0,392 dapat dinyatakan berarti bahwa ada pengaruh negatif antara stres kerja dengan kinerja perawat yang berarti apabila stres kerja meningkat maka kinerja perawat juga akan menurun.

Nilai koefisien regresi kelelahan kerja (X2) sebesar -0,401 dapat dinyatakan berarti bahwa ada pengaruh negatif antara kelelahan kerja dengan kinerja perawat yang berarti apabila kelelahan kerja meningkat maka kinerja perawat akan menurun.

Nilai koefisien regresi motivasi kerja (X3) sebesar 0,285 dapat dinyatakan berarti bahwa ada pengaruh positif antara motivasi kerja dengan kinerja perawat yang berarti apabila motivasi kerja meningkat maka kinerja perawat juga akan meningkat.

Tabel 13.

Hasil Uji Kelayakan Model (Uji F)

\begin{tabular}{|c|c|c|c|c|c|c|}
\hline \multicolumn{2}{|c|}{ Model } & $\begin{array}{c}\text { Sum of } \\
\text { Squares }\end{array}$ & Df & $\begin{array}{l}\text { Mean } \\
\text { Square }\end{array}$ & $F$ & Sig. \\
\hline \multirow[t]{3}{*}{1} & Regression & 350,981 & 3 & 116,994 & 76,443 & $.000^{\mathrm{b}}$ \\
\hline & Residual & 188,248 & 123 & 1,530 & & \\
\hline & Total & 539,228 & 126 & & & \\
\hline
\end{tabular}

Sumber : Data Diolah, 2018 
Hasil Uji F menunjukkan nilai signifikan yakni 0,000 kurang dari 0,05 (0,000 $<0,05)$ sehingga $\mathrm{H}_{0}$ ditolak. Dengan kata lain Stres Kerja, Kelelahan Kerja (Burnout), dan Motivasi Kerja berpengaruh dan signifikan terhadap variabel terikatnya yaitu Kinerja Perawat.

Tabel 14. Hasil Analisis Koefisien Determinasi $\left(\mathbf{R}^{\mathbf{2}}\right)$

\begin{tabular}{ccccc}
\hline Model & $\mathrm{R}$ & $\mathrm{R}$ Square & Adjusted $R$ Square & $\begin{array}{c}\text { Std. Error of the } \\
\text { Estimate }\end{array}$ \\
\hline 1 & $0,820^{\mathrm{a}}$ & 0,651 & 0,642 & 1,237 \\
\hline Sumber : Data Diolah, 2018 & & &
\end{tabular}

Besarnya nilai $\mathrm{R}$ square adalah sebesar 0,651 yang artinya sebesar 65,1 persen variasi kinerja perawat dipengaruhi oleh stres kerja, kelelahan kerja, dan motivasi kerja, sedangkan sisanya sebesar 34,9 persen dipengaruhi oleh faktor lain yang tidak dimasukkan ke dalam model penelitian.

Tabel 15.

Hasil Uji t

\begin{tabular}{|c|c|c|c|c|c|c|}
\hline & \multirow{2}{*}{ Model } & \multicolumn{2}{|c|}{$\begin{array}{c}\text { Unstandardized } \\
\text { Coefficients }\end{array}$} & \multirow{2}{*}{$\begin{array}{c}\text { Standardized } \\
\text { Coefficients }\end{array}$} & \multirow[t]{2}{*}{$\mathrm{T}$} & \multirow[t]{2}{*}{ Sig } \\
\hline & & B & $\begin{array}{c}\text { Std. } \\
\text { Error }\end{array}$ & & & \\
\hline \multirow[t]{4}{*}{1} & (Constant) & 21,257 & 1,680 & & 12,654 & 0,000 \\
\hline & Stres Kerja & $-0,392$ & 0,174 & $-0,238$ & $-2,261$ & 0,026 \\
\hline & $\begin{array}{l}\text { Kelelahan Kerja } \\
\text { (Burnout) }\end{array}$ & $-0,401$ & 0,166 & $-0,267$ & $-2,417$ & 0,017 \\
\hline & Motivasi Kerja & 0,285 & 0,050 & 0,401 & 5,726 & 0,000 \\
\hline
\end{tabular}

Hasil uji t, diketahui bahwa variabel stres kerja memiliki nilai koefisien beta negatif sebesar $-0,238$ dengan nilai Sig. sebesar 0,026. Nilai Sig. 0,026 $<0,05$ mengindikasikan bahwa $\mathrm{H}_{1}$ diterima. Dengan kata lain stres kerja berpengaruh negatif dan signifikan terhadap kinerja.

Variable kelelahan kerja memiliki nilai koefisien beta negatif sebesar -0,267 dengan nilai Sig. sebesar 0,017. Nilai Sig. 0,017 < 0,05 mengindikasikan bahwa 
$\mathrm{H}_{2}$ diterima. Dengan kata lain kelelahan kerja berpengaruh negatif dan signifikan terhadap kinerja.

Variable motivasi kerja memiliki nilai koefisien beta positif sebesar 0,401 dengan nilai Sig. sebesar 0,000. Nilai Sig. 0,000 $<0,05$ mengindikasikan bahwa $\mathrm{H}_{3}$ diterima. Dengan

Pengujian hipotesis pada pengaruh stres kerja terhadap kinerja perawat menunjukkan bahwa stres kerja berpengaruh negatif dan signifikan terhadap kinerja perawat. Artinya semakin tinggi stres kerja di dalam rumah sakit maka kinerja yang dimiliki perawat RSD Mangusada akan menurun dan sebaliknya.

Hipotesis satu (H1) dalam penelitian ini menyatakan bahwa stres kerja berpengaruh negatif dan signifikan terhadap kinerja perawat. Berdasarkan hasil distribusi jawaban responden variabel stres kerja diketahui bahwa stres kerja memiliki pengaruh yang signifikan. Hasil yang signifikan ini disebabkan oleh indikator salah satunya yaitu bahwa perawat merasa stres karena kurang nyaman dengan beberapa rekan kerjanya di kantor. Sehingga dapat disimpulkan bahwa hasil ini menerima $\mathrm{H} 1$ yakni stres kerja berpengaruh negatif dan signifikan terhadap kinerja.

Hasil penelitian ini sesuai dengan penelitian yang dilakukan oleh Chandra (2014), Mohtaram (2015), Satriyo (2014) dan Hera \& Hasmin (2016) menunjukan hasil negatif signifikan terhadap kinerja. Wartono (2017) yang meneliti tentang pengaruh stres kerja terhadap kinerja karyawan (studi pada karyawan majalah mother and baby) juga menunjukan pengaruh yang negatif signifikan. Disamping 
itu penelitian Widyastuti (2015) dan Julvia (2016) juga menunjukan hal yang sama yaitu stres kerja berpengaruh negatif signifikan terhadap kinerja.

Pengujian hipotesis pada pengaruh kelelahan kerja terhadap kinerja perawat menunjukkan bahwa kelelahan kerja berpengaruh negatif dan signifikan terhadap kinerja. Artinya semakin tinggi kelelahan kerja pada rumah sakit maka kinerja yang dimiliki perawat RSD Mangusada akan menurun begitu pula sebaliknya.

Hipotesis dua (H2) dalam penelitian ini menyatakan bahwa kelelahan kerja berpengaruh negatif dan signifikan terhadap kinerja perawat. Berdasarkan hasil distribusi jawaban responden variabel kelelahan kerja diketahui bahwa kelelahan kerja memiliki pengaruh yang signifikan. Hasil yang signifikan ini disebabkan oleh indikator salah satunya perawat merasa lelah saat melayani pasien yang banyak. Sehingga dapat disimpulkan bahwa hasil ini menerima $\mathrm{H} 2$ yaitu kelelahan kerja berpengaruh negatif dan signifikan terhadap kinerja.

Hasil penelitian ini sesuai dengan penelitian yang dilakukan Erdilek, Tezergil, \& Kose (2014), Satriyo (2014), Hera \& Hasmin (2016) yang menunjukkan kelelahan kerja berpengaruh negatif dan signifikan terhadap kinerja. Hummayoun (2015) yang meneliti dampak burnout terhadap kinerja karyawan pada industri perbankan menunjukan adanya pengaruh yang negatif signifikan. Adnyaswari (2017) yang meneliti tentang pengaruh burnout terhadap kinerja perawat rawat inap di RSUP Sanglah memberikan pengaruh negatif signifikan terhadap kinerja perawat.

Pengujian hipotesis pada pengaruh motivasi kerja terhadap kinerja perawat menunjukkan bahwa motivasi kerja berpengaruh positif dan signifikan terhadap 
kinerja. Artinya semakin tinggi motivasi kerja pada rumah sakit maka kinerja yang dimiliki perawat RSD Mangusada akan meningkat begitu pula sebaliknya.

Hipotesis tiga $(\mathrm{H} 3)$ dalam penelitian ini menyatakan bahwa motivasi kerja berpengaruh positif dan signifikan terhadap kinerja perawat. Berdasarkan hasil distribusi jawaban responden variabel motivasi kerja diketahui bahwa motivasi kerja memiliki pengaruh yang signifikan. Hasil yang signifikan ini disebabkan oleh indikator salah satunya perawat merasa termotivasi jika mendapatkan insentif yang lebih saat bekerja. Sehingga dapat disimpulkan bahwa hasil ini menerima $\mathrm{H} 3$ yaitu motivasi kerja berpengaruh positif dan signifikan terhadap kinerja.

Hasil penelitian ini sesuai dengan penelitian yang dilakukan Amianti \& Supriyanto (2012) yang menyatakan motivasi berpengaruh positif dan signifikan terhadap kinerja karyawan. Penelitian Larasati \& Gilang (2014) juga menunjukan pengaruh signifikan positif dalam penelitiannya tentang pengaruh motivasi kerja terhadap kinerja karyawan wilayah telkom Jabar barat utara (witel bekasi). Menurut penelitian Widnyana, Sintaasih, \& Riana (2016) dan Muliani, Sudibia, \& Sintaasih (2017) juga menunjukan hasil yang sebanding bahwa motivasi kerja berpengaruh positif terhadap kinerja.

Faktor yang berhubungan dengan kinerja perawat dalam penelitian ini adalah stres kerja, kelelahan kerja dan motivasi kerja. Implikasi teoritis yang berkaitan dengan kinerja secara konsisten memperkuat teori sebelumnya bahwa stres kerja, kelelahan kerja dan motivasi kerja mempengaruhi kinerja perawat. Dalam penelitian ini menyatakan bahwa stres kerja memiliki pengaruh negatif dan signifikan terhadap kinerja perawat, hal ini menunjukkan bahwa jika rumah 
sakit ingin kinerja perawat selalu baik maka harus memperhatikan indikatorindikator yang membuat perawat stres seperti hubungan antar perawat yang kurang baik, pembagian jadwal kerja, serta pearasaan cemas perawat yang mengalami masalah keluarga di rumah.

Hasil penelitian berikutnya menyatakan bahwa kelelahan kerja berpengaruh negatif dan signifikan terhadap kinerja perawat. Hal ini berarti semakin tingginya kelelahan perawat dalam bekerja akan menyebabkan semakin menurunnya kinerja perawat itu sendiri. Maka dari itu pihak rumah sakit harus tetap menjaga agar perawat tidak terlalu merasa lelah walaupun merasa monoton dalam bekerja, melayani banyak pasien ataupun jika terjadi perasaan sinis antar perawat saat bekerja.

Hasil penelitian yang terakhir menyatakan bahwa motivasi kerja berpengaruh positif dan signifikan terhadap kinerja perawat, hal ini menunjukkan bahwa semakin perusahaan memotivasi perawat maka kinerja perawat tersebut juga akan semakin membaik karena pada dasarnya setiap pegawai selalu membutuhkan motivasi saat bekerja. Hal ini mendukung penelitian yang telah diungkapkan pada hipotesis penelitian, sehingga dapat disimpulkan bahwa penelitian ini mendukung serta memperjelas hubungan antara variabel stres kerja, kelelahan kerja, motivasi kerja, dan kinerja.

Penelitian ini diharapkan akan memberikan kontribusi positif bagi semua pihak khususnya perawat dan RSD Mangusada. Bagi perawat hendaknya ikut ambil bagian dan memiliki loyalitas tinggi untuk tetap menjaga dan meningkatkan kinerja, karena merupakan suatu kepuasan tersendiri bagi perawat jika mampu menjaga 
kinerjanya terhadap rumah sakit. Bukan hanya bagi diri tetapi akan berdampak kepada hasil pelayanan terhadap pasien juga. Bagi pihak RSD Mangusada dalam menjaga kinerja perawat sebaiknya memperhatikan stres kerja, kelelahan kerja (burnout) dan motivasi kerja perawat agar dapat diperhatikan dengan baik dan disesuaikan dengan apa yang telah ditetapkan manajemen rumah sakit karena halhal tersebut akan mempengaruhi kualitas pelayanan RSD Mangusada.

Terdapat keterbatasan yang mempengaruhi kondisi dari penelitian yang dilakukan. Adapun keterbatasan dalam penelitian ini yaitu Jumlah responden hanya 127 orang perawat dan hanya berasal dari perawat tetap RSD Mangusada, sehingga hasil penelitian ini hanya dapat diterapkan di lingkungan kerja RSD Mangusada dan tidak dapat digeneralisasi pada lingkungan rumah sakit lain. Faktor-faktor yang mempengaruhi kinerja perawat dalam penelitian ini hanya terdiri dari tiga variabel, yaitu stres kerja, kelelahan kerja dan motivasi kerja, sedangkan masih banyak faktor lain yang mempengaruhi kinerja.

\section{SIMPULAN}

Berdasarkan dari hasil analisis dan hasil pembahasan maka dapat ditarik simpulan stres kerja berpengaruh negatif dan signifikan terhadap kinerja perawat. Hal ini menunjukan semakin tinggi stres kerja perawat maka kinerja perawat semakin menurun.

Kelelahan kerja berpengaruh negatif dan signifikan terhadap kinerja perawat. Hal ini berarti semakin tingginya kelelahan kerja yang dirasakan perawat dalam rumah sakit, maka kinerja perawat semakin menurun. 
Motivasi kerja berpengaruh positif dan signifikan terhadap kinerja perawat. Hal ini menunjukan bahwa semakin tinggi motivasi perawat dalam bekerja maka kinerja perawat tersebut akan semakin meningkat.

Saran yang dapat diberikan berdasarkan hasil analisis dan pembahasan adalah menanggulangi stres kerja yang dialami oleh perawat, maka dapat memperhatikan jadwal kerja yang dijalani perawat. Diharapkan jadwal tersebut dapat disesuaikan kembali agar lebih sesuai dengan kemampuan perawat dalam bekerja. Memperhatikan kenyamanan perawat dalam bekerja dengan menjalin komunikasi yang baik antar pekerja.

Hal yang perlu diperbaiki selanjutnya adalah proporsi kerja perawat dalam melayani jumlah pasien. Semakin banyak pasien yang dilayani akan mempercepat perawat untuk merasa lelah. Hubungan antar perawat juga harus dipantau, jika terdapat konflik diharapkan manajer dapat dengan cepat menanggulanginya. Hal ini perlu diperhatikan agar perawat tidak cepat lelah dalam bekerja.

Motivasi manjadi hal yang penting untuk diperhatikan karena menentukan kinerja perawat. Manajer diharapkan dapat menanamkan rasa tanggungjawab terhadap perawat karena tugasnya adalah melayani pasien. Pujian dan insentif yang cukup juga sangat diharapkan atas pencapaian yang telah dilakukan perawat dalam bekerja sehingga kinerja perawat akan selalu baik dan terjaga.

\section{REFERENSI}

Adnyaswari, N. A. (2017). Pengaruh Dukungan Sosial Dan Burnout Terhadap Kinerja Perawat Rawat Inap RSUP Sanglah. E-Journal Management Unud, $1(8), 120-135$. 
Almustofa, R. (2014). Pengaruh Lingkungan Kerja, Motivasi Kerja, Disiplin Kerja Terhadap Kinerja Pegawai(Studi Pada Pegawai Perum Bulog Divisi Regional Jakarta). Jurnal Administrasi Bisnis, 1(2), 1-20.

Amianti, I., \& Supriyanto. (2012). Pengaruh Motivasi Kerja Terhadap Kinerja Karyawan Bagian Marketing Bank Syariah (Studi kasus Pada Karyawan PT. BPRS Pemerintah Kota Bekasi). Maslahah, 1(1), 1-20.

Ardana, K., Mujiati, N. W., \& Sriathi, A. A. A. (2009). Perilaku Keorganisasian. Jogjakarta: Graha ilmu.

Bhanugopan, R., \& Fish, A. (2006). An Empirical Investigation of Job Burnout among Expatriates. Personnel Review, 35(1), 1-12.

Chandra, J. (2014). Pengaruh Stres Kerja dan Kepuasan Kerja Terhadap Kinerja Karyawan Pada P.T. Lie Fung Surabaya. Jurnal Administrasi Bisnis, 1(2), 120.

Endri, S., \& Sudibia, G. A. (2015). Pengaruh Kepemimpinan Transformasional, Motivasi dan Burnout Terhadap Kinerja Karyawan Outsourcing RRI Mataram-Bali. E-Jurnal Manajemen Unud, 4(8), 1-20.

Erdilek, M. K., Tezergil, S. A., \& Kose, A. (2014). Does Motivation Mediate the Job Performance and Burnout Evidence from Turkish Banking Sector. American International Journal of Social Science, 3(6), 1-20.

Hera, R., \& Hasmin. (2016). Pengaruh Konflik Peran Ganda, Beban Kerja Dan Kelelahan Kerja (Burnout) Dengan Kinerja Perawat Wanita Di RSUD I Lagaligo Kabupaten Luwu Timur. Jurnal Administrasi Bisnis, 1(1), 1-10.

Hummayoun, N. (2015). Impact Of Burnout On Employees Performance: An Analysis Of Banking Industry. Management and Sustainable Development, 11(1), 1-10.

Julvia, C. (2016). Pengaruh Stres Kerja Dan Konflik Kerja Terhadap Kinerja Karyawan. Jurnal Imiah Manajemen Bisnis, 16(1), 1-23.

Larasati, S., \& Gilang, A. (2014). Pengaruh Motivasi Kerja terhadap Kinerja Karyawan Wilayah Telkom Jabar Barat Utara (Witel Bekasi). Jurnal Universitas Telkom, 1(2), 1-10.

Luthans, F. (2006). Organizational Behavior (Ninth Edit). New York: Mc Graw Hill.

Mangkunegara, A. P. (2005). Evaluasi Kinerja. Bandung: Refika Aditama. 
Maslach, C., \& Leiter, M. . (2008). Early Predictors Of Job Burnout And Engagement. Journal of Applied Psychology, 9(3), 498-512.

Maslow, A. (2010). Motivation and Personality. Jakarta: Rajawali.

Mohtaram, N. T. (2015). Dispositional Effects on Job Stressors and Job Satisfaction: The Role of Core Evaluations. Social and Behavioral Sciences, $18(1), 61-68$.

Murty, W. A., \& Hudiwinarsih, G. (2012). Pengaruh Kompensasi, Motivasi dani Komitmen Organisasional terhadap Kinerja Karyawan Bagian Akuntansi pada Perusahaan Manufaktur di Surabaya. The Indonesian Accounting Review, 2(2), 215-228.

Rice, P. L. (2005). Stres and Health. London: Brooks Cole Publishing Company.

Robbins, S. P. (2008). Perilaku Organisasi. Jakarta: PT. Indeks.

Satriyo, M. (2014). Stres Kerja Terhadap Burnout Serta Implikasinya Pada Kinerja. Jurnal Manajemen \& Akuntansi, 3(2), 1-20.

Wartono, T. (2017). Pengaruh Stres Kerja Terhadap Kinerja Karyawan (Studi Pada Karyawan Majalah Mother And Baby). Jurnal Ilmiah Prodi, 1(1), 1-12.

Widnyana, Sintaasih, \& Riana. (2016). Efek Pemoderasian Status Kepegawaian Pada Pengaruh Motivasi Dan Komitmen Organisasional Terhadap Kinerja Karyawan. Jurnal Manajemen, 10(1), 1-10.

Widyastuti, N. (2015). Pengaruh Stres Kerja Dan Beban Kerja Terhadap Kinerja SKPD Kabupaten Sintang Kalimantan Barat. Jurnal Maksipreneur, 4(2), 1527.

Yanuar, S., \& Mulyadi, H. (2010). Pengaruh Faktori Job Demand terhadap Kinerja dengan Burnout sebagai variable moderating pada karyawan bagian produksi PT.Tripilar Beton Mas Salatiga. Jurnal Ilmu Manajemen, 3(6), 47-68. 